\title{
Changes In Blood Sugar Level After Cycling For 30 Minutes
}

\author{
$1^{\text {st }}$ Ramdan Pelana \\ Faculty of Sport Science \\ Universitas Negeri Jakarta \\ Jakarta, Indonesia \\ ramdanpelana@unj.ac.id
}

\begin{abstract}
The purpose of this study is The change in blood sugar levels after cycling for 30 minutes. This was an experimental study. The criteria of this study are 17 years old, weight $50-55 \mathrm{~kg}$, glucose level $110-140 \mathrm{mg} / \mathrm{dl}$. The results of the calculation of blood glucose values before and after cycling obtained the difference of average 25.2. The calculation states that there is a decrease in blood sugar level after doing the cycling activity for $\mathbf{3 0}$ minutes.
\end{abstract}

Keywords- blood sugar level, diabetes, insulin, cycling 30 minutes introduction

\section{INTRODUCTION}

A series of our daily activities make it difficult for many people to do sports in the midst of our busy routine, whereas good exercise needed to maintain our fitness. Health should be maintained because healthy is expensive, many people have high wealth and position but can not enjoy it because his body is no longer healthy because of the wrong lifestyle. Many people consume high-calorie foods but not balanced with physical activity often cause various health problems such as diabetes.

Diabetes is a disease that needs to be aware of. Most people realize they have diabetes after they are aged. Diabetes is one of the diseases that arise due to poor lifestyle. The World Health Organization (WHO) estimates that 177 million people worldwide suffer from diabetes [15].

Sekolah Menengah Atas Negeri 3 Serang is one of the public high schools in Serang city that has implemented Full Day School and has a fairly solid academic routine for their students. The students of SMAN 3 Serang start the lesson at 07.00 a.m. until 15.30 p.m.

SMAN 3 Serang is one of the public schools in Serang City that uses domicile system in the selection of their new students. A total of $30 \%$ seats are reserved for those who live in areas close to SMAN 3 Serang .

Blood is a body fluid that flows in the blood vessel system found in humans and animals. Blood sugar contained in the body is produced by foods that contain carbohydrates, proteins, and fats. Blood is a vehicle or medium to transport various nutrients throughout the body. Blood functions in transporting oxygen, nutrients and metabolic waste from the heart to the whole body and back to the heart [16].

All types of carbohydrates that are consumed by human beings are either complex carbohydrate types (rice, potatoes, bread, cassava etc) or simple carbohydrates (glucose, sucrose, fructose) will be converted into glucose in the body. This formed glucose can then be stored as energy reserves as glycogen in the liver and muscles and can be stored in the blood or can also be brought into the cells of the body in need [17].

Glucose contained in the bloodstream is what is referred to as blood sugar levels. Glucose levels in arteries is 15-30 mg / $\mathrm{dl}$ higher than in veins. Blood glucose concentration or glucose level is tightly regulated in the body. Glucose that stream throughout the body is the main source of energy for the body's cells.

Heart Glucostat. The liver has the ability to maintain blood sugar concentrations in order to remain normal in some circumstances. During exercise, muscle calorie needs are initially filled with glycogenolysis in the muscle and increased glucose uptake. Plasma glucose is initially elevated due to increased glycogenolysis of the liver but may decrease due to heavy and prolonged exercise [5].

The plasma glucose level at one time is determined by the balance between the amount of glucose that enters the bloodstream and the amount that leaves it. Five percent of glucose consumed directly in conversion to fat. The rest is metabolized in muscles and other tissues. At the time of fasting, the liver glycogen is disport and the liver adds glucose to the bloodstream. If the fast is longer, glycogen runs out and there is an increase in gluconeogenesis of amino acids and glycerol in the liver. There is a moderate decrease in plasma glucose to about $60 \mathrm{mg} / \mathrm{dL}$ during prolonged hunger in normal people, but no symptoms of hypoglycemia occur because gluconeogenesis prevents further reduction. 
Table 1. Blood Glucose Levels in Several Circumstances and Times

\begin{tabular}{cc}
\hline Time / Circumstances & $\begin{array}{c}\text { Blood Sugar Level } \\
\text { (mg/dl) }\end{array}$ \\
\hline $\begin{array}{c}\text { In the morning (right } \\
\text { after wake up) }\end{array}$ & $70-100$ \\
\hline Before Lunch & $70-110$ \\
\hline 2 Hours after lunch & $110-140$ \\
\hline $\begin{array}{c}\text { Fasting blood sugar } \\
\text { level }\end{array}$ & $95-135$ \\
\hline
\end{tabular}

Source: Neil F. Gordon. Diabetes: Your Complete Exercise Guide. Canada, Human Kinetics Publiser, 1993.

Thus, William F. Ganong points out that the liver functions as a kind of "glucostat", which will maintain blood sugar levels. The liver can also help dispart fructose and galactose into glucose and glucose into fat. This can happen because of hormonal activity secreted by the islets of Langerhans in the pancreas. Two of these hormones, insulin and glucagon, have important functions in regulating metabolism between carbohydrates, proteins and fats. The third hormone, somatostatin plays a role in regulating the secretion of the islets of Langerhans cells, and the fourth physiological function of the hormone, the pancreatic polypeptide is unknown [6].

The hormones that play an important role in the regulation of blood sugar levels to remain in normal circumstances:

Insulin. Insulin is a hormone that is naturally secreted by the pancreas into the bloodstream and then circulates throughout the body. The function of insulin is to help blood sugar entering the cells. If insulin is very little even none or can not function normally, then the sugar can not get into the cell. As a result sugar can not be used to make energy. This situation causes cells to starve.

The main regulator of insulin secretion is induced by the direct feedback effect of blood sugar levels on the pancreas. Glucose permeates the islets of the Langerhans easily and the rate of income is not influenced by insulin. If blood sugar levels that promote pancreas increase (in mice above $110 \mathrm{mg} / \mathrm{dl}$ ), insulin secretion in the blood of the pancreatic venosa increases, if the levels are normal or low, the speed of insulin secretion is slow.

Insulin is an anabolic system, increasing the deposits of glucose, fatty acids and amino acids. Inclusion of glucose into the skeletal muscle increases without insulin. Insulin facilitates the entry of glucose into cells by increasing the number of glucose transporters in the cell membrane.

Without insulin, the entry of glucose into the skeletal muscle may increase during exercise. Doing regular exercise can result in a prolonged increase insulin sensitivity. Exercise can also cause hypoglycemia due to increased glucose uptake in the blood. Sugar that can not enter the cells will be in high concentrations in the blood, if it lasts long it can cause diabetes.
Glucagon is glycogenolytic, gluconeogenetic, and lipolytic. It increases blood sugar because it stimulates adenylate cyclase in liver cells. Adenylate cyclase tends to activate phosphorylase therefore it increase the breaking of glycogen. Like insulin, glucagon is a protein hormone produced in the pancreas, glucagon is an insulin balancer.

Glucagon is also catabolic, mobilizing glucose, fatty acids and amino acids from its reserves into the blood. Approximately 4-6 hours after eating, the level of glucose in the blood is reduced. This triggers the production of glucagon in the pancreas, when the pancreas secretes insulin glucagon will be pressed. Glucagon signs the liver and muscles to dispart glycogen into glucose and pull it back into the bloodstream, keeping your blood sugar levels low.

Eating proteins and infusing various amino acids increases glucagon secretion. It seems that in this case, what suitable and potent are glucogenic amino acids, because they are amino acids that are converted into glucose in the liver under the influence of glucagon. Increased glucagon secretion after eating protein is also beneficial, as amino acids stimulate insulin secretion, and the secreted glucagon prevents the development of hypoglycemia while insulin facilitates the storage of absorbed carbohydrates, fats and lipids. Glucagon secretion increases hunger time. It reaches its peak on the third day of fasting, at the time of maximum gluconeogenesis. After that, plasma glucagon levels decrease the time fatty acids and ketones become the main source of energy.

Glucagon does not cause glycogenolysis in the muscles. It increases the gluconeogenesis of the amino acids available in the liver and increases the speed of its metabolism.

These two hormones between insulin and glucagon are opposite in their ways of working, and in many cases are secreted in opposite ways.

Cycling is one of the best activities to improve heart fitness. Heart fitness is measured by aerobic capacity, ie the ability to exercise large muscles and whole bodies at moderate to high intensity levels for long periods of time [4].

Cycling becomes the best way to practice for 20 to 30 minutes every day, 3 to 5 days each week to get good health and wellness. In Bikemania, it is explained that the human body is designed to move. Research has shown that exercising regularly for 30 minutes in one day provides many benefits, even though the 30 minute time is divided into two or three different sessions. If you are over 40 years of age, being overweight or never exercising regularly for long periods of time, it is important that you consult your doctor first before starting a cycling program [8].

Cycling is identic with physical activity or physical exercise that can be done by everyone. Physical activity includes activities that involve body movement. Therefore, cycling can spur heart rate in accordance with the target we want. Physical activity such as sport is one form of work. To be able to do work like exercise our body needs energy.

When we exercise (cycling), muscle energy requirements are initially fulfilled by muscle glycogenolysis, after the glycogen in the muscle is reduced there will be an increase in glucose uptake in the blood. Plasma glucose initially falls due 
to muscle retrieval but may return to normal due to glycogenolysis of the liver (liver glucostat).

Fulfillment of energy during physical activity is obtained through metabolic processes. Metabolism is a chemical process that allows cells to survive. In general, sports activities consist of two types of activities: aerobic activity and anaerobic activity. Aerobic activity is a low to moderate intensity exercise activity that can be done continuously and over long periods of time.

Aerobic exercise involves large muscle groups and is performed in moderately low intensity, as well as in considerable time. Aerobic exercise is maintained from $15-20$ minutes to several hours in a single exercise [11].

The formation of energy in the muscle is as follows:

- Aerobics

- Glycogen and free fatty acids + P + ADP + O2 $\leftrightarrow \mathrm{CO} 2+$ $\mathrm{H} 2 \mathrm{O}+\mathrm{ATP}$.

- Anaerobic

1. $\mathrm{ATP} \nrightarrow \mathrm{ADP}+\mathrm{P}+$ Free energy

2. Creatine posphat $+\mathrm{ADP} \leftrightarrow$ Kreatin + ATP

3. Glycogen / Glucose $+\mathrm{P}+\mathrm{ADP} \leftrightarrow$ Lactate Acid + ATP (Astrand M.D, 1970).

Aerobic exercise can be done with low to moderate intensity cycling. Here are some models of cycling exercises in low intensity zones and short periods of time.

The use of energy at various cycling speeds is more or less as follows [13]:

$9.6 \mathrm{~km} / \mathrm{hr}: 270 \mathrm{Kal} / \mathrm{hr}$

$12.8 \mathrm{~km} / \mathrm{hr}: 330 \mathrm{Kal} / \mathrm{hr}$

$16 \mathrm{~km} / \mathrm{hr}: 400 \mathrm{Kal} / \mathrm{hr}$

$17.6 \mathrm{~km} / \mathrm{hr}: 450 \mathrm{Kal} / \mathrm{hr}$

$19.2 \mathrm{~km} / \mathrm{hr}: 550 \mathrm{Kal} / \mathrm{hr}$

$20.8 \mathrm{~km} / \mathrm{hr}: 650 \mathrm{Kal} / \mathrm{hr}$

Cycling for 30 minutes at a speed of $26 \mathrm{~km} / \mathrm{h}$ then there will be a working effect that will affect the concentration of blood sugar levels. Blood sugar in the blood will decrease due to increased glucose uptake in the muscle but blood sugar levels will return to normal conditions due to the presence of the liver as glucostat that keep blood sugar concentration levels.

Table 2. Model Exercise 1 Slow Rider.

\begin{tabular}{cc}
\hline Distance & 5 mil \\
\hline Time & 20 minutes \\
\hline Terrain & Flat Road \\
\hline Speed & Slow. Switch if \\
& necessary for constant \\
& workload. \\
& Keep the pedal round at \\
& 85-90 RPM \\
\hline Workload & $60-65 \%$ heart rate max \\
\hline
\end{tabular}

Table 3. Model Exercise 2 Slow Rider

\begin{tabular}{cc}
\hline Distance & 6,25 mil \\
\hline Time & 25 minutes \\
\hline Terrain & Flat Road \\
\hline Speed & Slow. Switch if necessary \\
& for constant workload. \\
& Keep the pedal round at \\
& 85-90 RPM \\
\hline Workload & $60-65 \%$ heart rate max \\
\hline
\end{tabular}

Source: Chris, Carmichael. Bugar dengan Bersepeda. (Jakarta: P.T Raja Grafindo, 2003), h.52.

Table 4. Model Exercise 3 Slow Rider

\begin{tabular}{c|c}
\hline Distance & 8 mil \\
\hline Time & 30 minutes \\
\hline Terrain & Flat Road \\
\hline Speed & $\begin{array}{c}\text { Slow. Switch if necessary } \\
\text { for constant workload. } \\
\text { Keep the pedal round at } \\
\text { 85-90 RPM }\end{array}$ \\
\hline Workload & $60-65 \%$ heart rate max \\
\hline
\end{tabular}

Source: Chris, Carmichael. Bugar dengan Bersepeda. (Jakarta: P.T Raja Grafindo, 2003), h.54.

The following is the number of normal pulses per minute:

1. Infants up to 1 year of age: $100-150$ times per minute

2. Children aged 1-10 years: $70-130$ times per minute

3. Children aged 10-18 years: $60-100$ times per minute

4. Adults: 50 - 80 times per minute (Evelyn C Pearce, 1999).

\section{Measuring maximum pulse rate \\ Formula: 220 - Age \\ Example: $220-17=203 / \mathrm{min}$. \\ Measuring Activity Percent}

After doing the activity cycling with a speed of $26 \mathrm{~km} / \mathrm{h}$ and a distance of $13 \mathrm{~km}$, then measured again his pulse and pulse rose to 130 - 135 / minutes.

\section{Formula :}

Activity Pulse / Pulse Maximum x 100\%

$=130 / 203 \times 100$

$=65 \%$

Thus, with a speed of $26 \mathrm{~km} / \mathrm{h}$ and a distance of $13 \mathrm{~km}$. The effort performed shows the pulse of activity $65 \%$ of maximum activity / maximum pulse rate. 


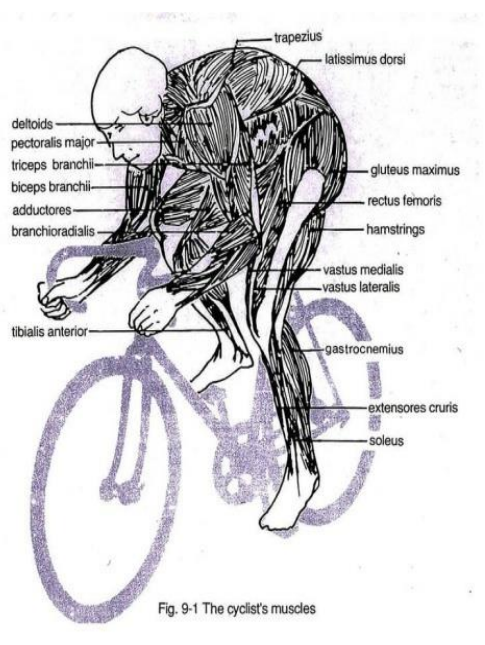

Fig. 1. Muscles that play a role during cycling

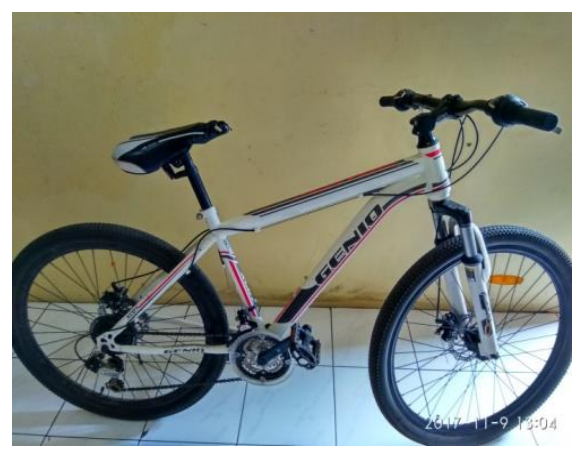

Fig. 2. Type of Bike Used

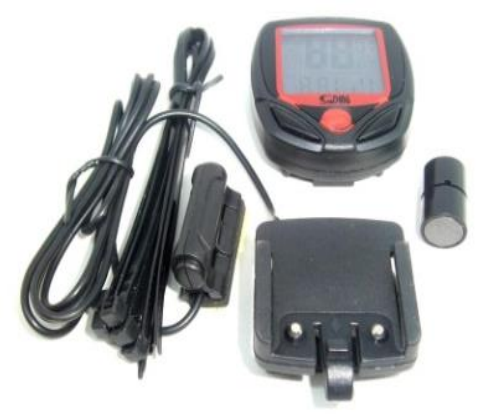

Fig. 3. Cyclomp

\section{METHOD}

This research is an experimental study. With a One Group Preliminary Test and Post Test design using purposive sampling method. Pretest done before treatment and post test after treatment. As for the free variable is a cycling exercise for 30 minutes, while the dependent variable is the blood sugar level.

The instruments used to collect data in this study are:

1. 4 pieces of blood glucose measuring device (Glucometer)

2. Strip for blood
3. Needles

4. Soft click

5. Alcohol

6. Tissue

7. Paper

8. Ballpoint

9. 10 units of mountain bikes using 3 gear 10.4 tester.

Data Collection Technique. In this study the data was taken by measuring blood sugar levels by 20 people testee, then testee do a blood sugar measurement test after fasting for 2 hours and after biking for 30 minutes with the following implementation procedures:

1. The sample is divided into 2 groups, the first group breakfast at 07.00 am and the second group at $07.30 \mathrm{pm}$.

2. Samples taken blood glucose level 2 hours after meal, first group at $09.00 \mathrm{pm}$ and second group at $09.30 \mathrm{pm}$.

3. Samples sit relaxed to the blood taken as much as one drop.

4. At first, prepare the glucometer tool along with chips and needle.

5. Then select one of the sample fingers and wipe with a cotton containing alcohol to sterilize.

6. Adjust the length of the needle according to the sample skin thickness. Then puncture until the blood comes out. And input the blood into the chip on the glucometer.

7. Wait for the result from the glucometer tool then record the result.

8. After the initial data obtained then the sample cycled with a speed of $26 \mathrm{~km} / \mathrm{hr}$ crossing the road to SMAN 3 Serang with a travel time of 30 minutes and mileage of approximately $13 \mathrm{~km}$.

9. After 30 minutes of cycling, the sample stops and will be retrieved immediately (post test).

10. Then select one of the sample fingers and wipe with a cotton containing alcohol to sterilize.

11. Adjust the length of the needle according to the sample skin thickness. Then puncture until the blood comes out. And input the blood into the chip on the glucometer.

12. Wait for the result of the glucometer tool and record the result.

13. Samples are not allowed to consume anything since the initial test (pre test) until completion of the final test (post test).

\section{RESULT AND DISCUSSION}

\section{A. Description}

Data collected at the time of the study was used as research data obtained from the initial test and the final test of blood sugar levels. The data can be described as: 
Table 5. Description Data Research Pre Test and Post Test Blood Sugar Levels

\begin{tabular}{ccc}
\hline Variable & $\begin{array}{c}\text { Initial } \\
\text { Blood } \\
\text { Sugar Level } \\
(\mathrm{mg} / \mathrm{dl})\end{array}$ & $\begin{array}{c}\text { Final Blood } \\
\text { Sugar Level } \\
(\mathrm{mg} / \mathrm{dl})\end{array}$ \\
\hline $\begin{array}{c}\text { Maximum } \\
\text { Value }\end{array}$ & 132 & 111 \\
\hline Minimum Value & 112 & 86 \\
\hline Average & 121,7 & 96,5 \\
\hline $\begin{array}{c}\text { Standard } \\
\text { Deviation }\end{array}$ & 5,48 & 7,87 \\
\hline Standard error & 1,25 & 1,80 \\
\hline
\end{tabular}

Table 6. Distribution Frequency Pre Test Blood Sugar Level

\begin{tabular}{cc}
\hline Class & Frequency \\
\cline { 2 - 2 } Interval & Presentage \\
\hline $112-116$ & $25 \%$ \\
\hline $117-121$ & $20 \%$ \\
\hline $122-126$ & $30 \%$ \\
\hline $127-131$ & $20 \%$ \\
\hline $132-136$ & $5 \%$ \\
\hline Total & $100 \%$ \\
\hline
\end{tabular}

Table 7. Distribution Frequency Post Test Blood Sugar Level

\begin{tabular}{cc}
\hline Class & Frequency \\
\cline { 2 - 2 } Interval & Presentage \\
\hline $86-91$ & $40 \%$ \\
\hline $92-97$ & $25 \%$ \\
\hline $98-103$ & $10 \%$ \\
\hline $104-109$ & $20 \%$ \\
\hline $110-115$ & $5 \%$ \\
\hline
\end{tabular}

Data descriptions in this study include the highest score, mean value, standard deviation, standard error, frequency distribution, and histogram of each variable. Here's the complete data:

The collected data on changes in blood sugar levels in the initial test showed a range of $132 \mathrm{mg} / \mathrm{dl}$ and the lowest value of $112 \mathrm{mg} / \mathrm{dl}$ with an average blood sugar level of $121.7 \mathrm{mg} /$ dl. Standard deviation (SD) of 5.48 and standard error (SE) of 1.25. This can be seen in the following frequency distributions:

Based on the table 3 it can be concluded that the largest frequency at intervals 122 - 126 with the percentage of $30 \%$ and the smallest frequency is at intervals $132-136$ with percentage of $5 \%$.

Based on the table 4 it can be concluded that the largest frequency at intervals 86 - 91 with a percentage of $40 \%$ and the smallest frequency is at intervals $110-115$ with percentage $5 \%$.

\section{B. Hypothesis testing}

The average score of the results obtained at the initial test was $121.7 \mathrm{mg} / \mathrm{dl}$ and in the final test of $96.5 \mathrm{mg} / \mathrm{dl}$. From the average data on the initial test and the final test on blood sugar tests showed a decrease in the results obtained. From result of data analysis obtained difference of mean 25,2 with standard deviation difference (SDd) that is equal to 5,02 and standard error difference average equal to 1,15 in subsequent calculation obtained t-count equal to 21,91 and t-table value with degree of freedom (n-1) and significant level of $\alpha=0,05$ is 2,09 . Since the $\mathrm{t}$-count is greater than the t-table value, it indicates that $(\mathrm{H} 0)$ is rejected and (H1) is accepted.

This means that the results of the calculation stated that the activity of cycling for 30 minutes can lower blood sugar levels in students of class XI SMA Negeri 3 Serang

\section{CONCLUSION}

Based on the problems presented and supported by the theoretical descriptions, existing research data, and analysis of data that has been done, it can be concluded that: There is a 30minute cycling effect on the change of blood sugar levels in students of grade XI SMAN 3 Serang.

\section{REFERENCES}

[1] Afian, Nugros, 2011. "All About Bycycle" IEEE Transl. Kupas Tuntas Sepeda. Yogyakarta: Dunia buku Publisher.

[2] Astrand M.D, 1970. Text Book of Work Physiology. Sidney: Student Edition.

[3] Arikunto, Suharsimi, 2010. "Research Procedure" IEEE Transl. Prosedur Penelitian. Jakarta: Rineka Cipta.

[4] Carmichael, Chris, 1996. "Health Throughg Cycling" IEEE Transl. Bugar Dengan Bersepeda. Jakarta: PT. Raja Grafindo.

[5] Ganong, William, F, 2001. "Medical Physiology Handout" IEEE Transl. Buku Ajar Fisiologi Kedokteran Edisi 20. Jakarta: EGC.

[6] Ganong, William, F, 2001. Fisiologi Kedokteran. (Review of Medical Physiology) Edisi 10. Jakarta: EGC.

[7] Tandra, Hans, 2017. "All You Have to Know About Diabet” IEEE Transl. Segala Sesuatu Yang Harus Anda Ketahui Tentang Diabetes. Jakarta: PT. Gramedia Pustaka Utama.

[8] Khalis, Ibnu, 2011. Bikemania. Jakarta: Flashbooks.

[9] Riduwan, 2010. "Basic of Statistic" IEEE Transl. Dasar-Dasar Statistika. Bandung: Alfabeta.

[10] Sharkey, Brian J, 2003. Kebugaran dan Kesehatan. Jakarta: PT. Raja Grafindo Persada.

[11] Sherwood, Lauralee, 2001. "Human Physiology $2^{\text {nd }}$ Edition" IEEE Trans. Fisiologi manusia edisi 2. Jakarta: EGC.

[12] Sudijono, Anas, 2012. "Introduction to Education Statistic" IEEE Trans. Pengantar Statistik Pendidikan. Jakarta: PT. Raja Grafindo Indonesia.

[13] Sumosardjuno, Sadoso, 1994. "Practice Knowledge of Health in Sport" IEEE Trans. Pengetahuan Praktis Kesehatan dalam Olahraga. Jakarta: PT. Gramedia Pustaka Utama.

[14] Suryabrata, Sumadi, 1983. "Research Methode" IEEE Trans. Metodologi Penelitian. Jakarta: CV. Rajawali.

[15] Tim Redaksi Vita Health, 2010. Diabetes. Jakarta: PT. Gramedia Pustaka Utama.

[16] Wiarto, Giri, 2012. “ Physiology and Sport” IEEE Trans. Fisiologi dan Olahraga. Surakarta: Graha Ilmu.

[17] M.Anwari Irawan, 2007. "Body's Metabolism Energy and Sport" IEEE Trans. Metabolisme energi tubuh \& olahraga. Sport Science Brief (Vol:01, ed. 07). 